Mahsa Sadat Razavi ${ }^{1}$

Maryam Soltan Beyad ${ }^{2}$

DOI: 10.31902/LL.2019.7.6

\title{
MAPPING THE JOURNEY: A STUDY OF MATURING FEMININITY IN ALICE MUNRO'S LIVES OF GIRLS AND WOMEN
}

\begin{abstract}
Opposed to the anxiety of influence supposedly suffered by male writers with regard to their predecessors, Gilbert and Gubar (2000) propounded the concept of anxiety of authorship to hold true for female writers. According to this theory, women joined in a sorority with their literary foremothers in their efforts to prove their worthiness in taking up the male vocation of writing. In Alice Munro's short story collection Lives of Girls and Women, the mother is ever-present in her daughter's mind, and their relationship is instrumental in her maturation as a woman and a writer. In this paper, the relationship between the two women is explained in terms of some of the notions put forth in Gilbert and Gubar's The Madwoman in the Attic, namely the angel/monster dichotomy, the anxiety of authorship, female double consciousness, infection in the sentence, and the parable of the cave. Using these concepts, it is aimed to show that although these notions were proposed as a model for 19th century woman writers, the modern-day Del is yet to come to terms with the anxiety of authorship and its accompanying problems.
\end{abstract}

Key words: Angel/Monster Dichotomy, Anxiety of Authorship, Female Double Consciousness, Infection in the Sentence, Parable of the Cave

\section{Introduction}

A comprehensive reading of some influential theories put forth by critics with regard to influence and its role in the maturation of writers revealed that they were not applicable to the case of a modern woman deciding to take up the pen: they either completely excluded women from consideration, or else focused solely on female writers and poets of $19^{\text {th }}$ century, whose situation markedly differed from that of their descendants. Thus, this research was conducted as an attempt to answer a pressing question: "How does the modern woman conceive of her art with relation to her female predecessors?" Alice Munro's Lives of Girls and Women was chosen for this discussion since it powerfully portrayed an emerging woman writer, and readily yielded to the task of providing a means for an analysis of influence as it affected the female literary scene.

Munro is regarded as a chronicler of women's lives, since them and their problems are extensively featured in her works. For instance, Thacker recognizes Lives of Girls and Women as "a feminist cri de Coeur" (2). Munro reverses the fairytale notion that women need protection, and portrays women managing to brave the world on their own (Löschnigg, 117). She usually investigates this notion with regard to the institution of marriage and gender roles as they are practiced in households. In her works, gender relies upon a "myth of home and family" in which

${ }^{1} \mathrm{PhD}$ candidate at the University of Tehran (Iran).

${ }^{2}$ Associate professor at the University of Tehran (Iran). 
a "father and mother [are] devoted to the moral and/or spiritual well-being of their offspring" (The Fantasy of Family 5). She also places special emphasis on how girls construct their gender identities; for instance, Del is shown encountering traditional gender roles, and despite her young age, choosing her own way of dealing with them (Chang 29). According to Chang, the central focal point for Munro is the notion of gender differences; how a boy adopts the attitudes deemed fit for his sex, while the girl, lacking a role model, uneasily adopts the inferior status that patriarchy assigns her (31). Munro moves beyond this male vs. female struggle, and presents the reader with a bigger and more comprehensive picture of life (Beran 77).

More often than not, she opts to show these gender roles play against each other in her depiction of family relations, highlighting those between mothers and daughters. Murphy identifies past connections, especially familial ones, to be important in Munro as well, particularly in Lives of Girls and Women (46). As governing matriarchs, mothers suffer all the trouble that their rule entails, while having to face being overthrown by their own offspring. They are recurring themes in Munro (43), and in family-focused stories, they are shown juggling different tasks, and sometimes feeing inadequate and insufficient in the roles traditional gender division ascribes them (Löschnigg 121-3). Hallvard Dahlie too recognizes Munro's mothers to be "unfulfilled and despairing" (215). Löschnigg states that "inseparable from the Munrovian mother-figure, who often also struggles to asset her identity as an artist, is the family home, which is depicted as the space against which male and female gender-scripts are pointedly accentuated" (123). Munro's relationship to the mother can be further explained in terms of personal issues; apparently, her own mother was ailing and in decline (Staines 33). Even when mothers are not ailing, they are resented, as if the constant battle between mothers and offerings has worn them throughout the years. But this battle for primacy is very important in the construction of one's character, and thus focused on in Munro, because "intimate yet attentive knowledge about one's mother leads to unsparing self-knowledge" (Hay 267). Lives of Girls and Women, with its foregrounding of the emotional ties between a mother and daughter, is very much based on Munro's experience, as John Metcalf reports her having said that the "emotional reality" of the work is completely based on her own life (58). The ever-lasting connection to the past usually seen in Munro is thus defined by Murphy:

“The typical writer in Munro's fiction is, then, ambivalent about her work but driven to do it. She struggles for representative accuracy, which failures of love and/or talent undercut. Munro's writers labor to connect memory and identity, and the problems inherent in such connection provide the central conflicts of Munro's fiction. But always, connection itself is the subsuming theme. Three kinds of connection are especially important to the Munro Weltanschauung: travel, the connection of one place to another in a journey replete with metaphorical meaning; change, the connection between past and present; and sexual love, probably the most fundamental and highly problematic of human connections". (45)

Logos et Littera: Journal of Interdisciplinary Approaches to Text 
Each of the three connections mentioned above find their ultimate representation in one of the three writers: Ada travels and leaves her family behind in order to carve out a separate identity for herself, Del hunts after sexual gratification as setting herself apart from her mother, and lastly, Munro changes names and immediate surroundings in order to explore her troubling bond with the Mother.

The Lives's affinities with the Küntslerroman gives the reader ample opportunity to view the woman-in-the-make that is Del; and its episodic nature highlights the stages she goes through in her maturation. Therefore, studying it in terms of the theories of Gilbert and Gubar can reveal the secrets behind Del's construction of identity, and can additionally provide the readers with a better understanding of how modern female writers conceive of their works.

\section{Discussion}

\section{Angel/Monster Dichotomy}

Because men have been the authoritative guardians of the pen, they have wielded great power over the way women are represented, castigating those who pose a threat to their own monarchy. Those women who refused to be shut off in these restrictive roles were invariably depicted as evil step mothers or envious queens whose greatest desire was to have their virginal daughters dead. Both these types show that women "can appear from certain points of view to stand both under and over (but really simply outside of) the sphere of culture's hegemony" (Ortner 86). As a result of this, women are bereft of autonomy, since they are not part of the culture, but are the Others that culture faces with either respect or hatred (Madwoman 1920).

Del is no stranger to this rigid dichotomy, as her small town is fraught with its manifestations, yet she has to decide where she stands with regard to it. As is typical of a Munro heroine, Del is fascinated with femininity, both behavioral and physical (Löschnigg 116-7). She can see different types of femininity represented by the women she has come to know in her lifetime. Mainly, she is indecisive about the two models advocated by her mother and the town: one requires her to repress her femininity and the other demands that she adhere to certain criteria for gendered behavior, but neither one of which particularly appeals to her (116).

Her Aunt Elspeth and Auntie Grace are good embodiments of the traditional and respectable female, who focus their tremendous energies on their house chores and gossiping (Lives 33-4). Observing Nile, her uncle's wife, Del realizes by "the aunt's gross exaggeration of femininity, ... that the gendered identity is not a natural characteristic of women and that the aunt has failed to internalize this" (Chang 32). Similarly, she is rather troubled by the way girls like those who work at the Creamery are always unnaturally impeccable, and is confused when Naomi begins dressing up and adhering to the same rigid standards (Lives 142-3). She herself tries to adapt to what is expected of her to some degree, as when during the episode at the Gay-la Dance Hall, she tries to adhere to the attitude expected of her, laughing and dancing so as to appease her male partner's demands (Lives 149, 51). Elsewhere, she allows Jerry to get away with his sexist slurs about the capacity of 
her brain (155), without pointing out to him how his ego is being protected by her "feminine sensibility" (Alice Munro 44).

On the other hand, Del gets to know the Jubilee monsters, or else, those women who openly defy the society's rules. Among them, her own mother stands out, since she practically engages in anything the town finds outrageous. Gilbert and Gubar have pointed out that a woman who chooses writing is viewed as a monster, immoral, and a sexually-defected or over-sexed demon (63); and Cinda Gault maintains that "Addie's association with the conventionally masculine narrative of facts in her encyclopedias" make her appear manly (448-9). To Del, her mother is the virgin who does not understand much of the realm of sexuality, something which is of grave importance to herself. Del hankers after the passion which their small town only acknowledges for men (Löschnigg 118). The mother's version of womanhood is not completely unappealing to Del, since it allows for her possession of an intellectual side; nonetheless, it fails to meet her other needs.

None of the options that this society permits Del sounds satisfactory: no matter the choice, she would lose a great portion of her identity. Therefore, she decides to transcend the dichotomy, fuse the two poles, and she thus phrases this desire: "I wanted men to love me, and I wanted to think of the universe when I looked at the moon" (Lives 144). Douglas Glover notes how Munro takes care to place the sexual and nonsexual side by side in her volume, thus fusing the two previously-separated spheres (98). These fusions could be attributed to Del, since she is the narrator of these tales. Thus, they may be regarded as Del's efforts in combining the two realms in her narrative in order to do away with the mutual exclusivity of the virginal and perversely sexual. Further, Del writes two women into fiction, and in their portrayal, fuses the two opposite stereotypes in order to depict women as they truly are.

The first woman to be sketched in the volume is her own mother, Ada. In her revised version of this ancient dichotomy, Del casts the mother as the harrowing virgin, a girl in a woman's body who is terrified of sex, and shies away from explicit sexuality. Her pureness is doubly glaring since from a young age she was sexually molested by her brother, a fact she never clearly expresses. Although according to Victorian codes of conduct, the angel had "no story of her own to tell," (Madwoman 22) and was merely a chasm to be filled with meaning as men deemed fit, Del shows Ada to be very outspoken indeed. She goes door to door selling encyclopedias, travelling the country roads (Lives 57), refusing to be circumscribed by her condition as a poor mother of two in rural Canada. She writes extensively to papers, advocating the use of birth control, using the pseudonym "Princes Ida" (69-70). The ironic undertones of a woman who is very much against sex and regards it as a subjugation to men advertising birth control under the pseudonym of Tennyson's angel is quite notable. This untraditional angel has fallen from grace, and satanically opposes religion.

Del's second and more original creation is presented in the epilogue to the collection, entitled "The Photographer", in which she tells the story of Caroline, a waif loosely based on Marion Sherriff, who courts her own doom. This is not a new strategy, since Ann Douglas had well shown how women engaged in a "domestication of death" by drinking vinegar, becoming anorexic, or tightly lacing 
their corsets so as to facilitate their illness and ultimate death. These methods were practiced in order to gain power, because the tombstone was "the sacred emblem in the cult of the overlooked" (202). Through dying, these subjugated women would be granted seat and dominance over the realm of the dead, or as Welsh puts it, "the power of an angel to save implies, even while it denies, the power of death" (182-3). The uniqueness of Del's Caroline, and the reason it helps break the dichotomy of female representation is that it is a modified Gothic tale. This description of Caroline will greatly help prove the point (Lives 192).

As Coral Ann Howells maintains, Del is not satisfied with the Gothic genre, because it displaces female knowledge and sexuality with fear and fleeing ("Alice Munro" 77). Thus, she creates a Gothic tale in which the anorexic dead woman is reincarnated and drags men to the underworld; precisely because she used to be the dead angel, she can be reborn as the monster who brings death to others. When she meets The Photographer, the death-like man with the camera, she gives herself to him "without the tender contempt, indifferent readiness she showed to other men, but with straining eagerness and hope and cries" (Lives 193). It may be claimed that because he is a photographer, he could be the embodiment of the male gaze that views women through a lens. When the photographer vanishes, and Caroline can feel "her womb swollen like a hard yellow gourd in her belly", she drowns herself in the river (193). What is noteworthy here is that Caroline is doubly killed by art, once by the art of the photographer who captures her, and the second time, by the woman who freezes her in words, that is, Del. In her tale, Del combines the angel and the monster to create Caroline, a woman who chooses her own doom, and in so doing, asserts her autonomy over patriarchy. Caroline is the one who runs after the photographer, and then at the end, walks into her own death in the river, but not before bringing death to her persecutors.

\section{Anxiety of Authorship: The Dreadful Vocation}

Anxiety of authorship results from women's uneasiness about their authorial will, since that amount of aggressiveness has been socially barred to them. This common anxiety creates a bond between women, making them effective members of a sorority against patriarchy (Madwoman 51). When being an author means "mistaking one's 'sex and way"' and "becoming an 'unsexed' or perversely sexed female", it makes a woman be seen as "a monster or freak" (34-5). Lives of Girls and Women, depicts three writers in their literary endeavors, namely Uncle Craig, Del, and Ada, and shows the reader how these efforts are received in society. As the stories in this book clearly demonstrate, when deciding to opt for a career in literature, one is bound to face different receptions according to one's sex. Uncle Craig, as the male writer depicted in the work, spends his days typing away endless trivia about Jubilee (Lives 32), trying to endow the town and his family with a grace he feels is owed to them. Although his efforts amount to nothing more than a family history, he and his work are treated with utmost respect by his sisters (32-3), who may be seen as quintessential members of a rural community. This is in direct contrast to the attitude the same ladies give Ada and her literary endeavors (36). Del, as a member of this sexist society, is not exempt from its attacks, and has to

Logos et Littera: Journal of Interdisciplinary Approaches to Text 
tolerate sexist slurs in addition to bearing the brunt of the criticism leveled at her mother.

In "Princess Ida", Del recounts how she became aware of the illegitimacy of her love for words. Out with her mother selling encyclopedias, she felt "complacent" and confident in her right to pursuing knowledge (Lives 59). She was not yet aware how to most members of her community, knowledge was "just oddity", as unseemly as "warts" (58). On one of these outings, and as she was about to recite the name of presidents, the reality of the situation dawned on her (59). After this realization, she felt physically sick, and never again agreed to recite from the encyclopedias. What Del experienced was the anxiety of authorship, which accompanied her realization that according to the town, her thirst for knowledge was an anomaly. Ada herself apparently does not experience such feelings of shame, as she claims, they are "the luxuries" that she "could never afford" (59). But this refusal of hers affects her daughter, since Del is the one who takes the brunt of the sneers directed at her mother. By way of alleviating this shame and anxiety, she decides to fight discreetly, a tactic which will be discussed fully in the next section.

\section{Female Double Consciousness: The Rebellious Second Sex}

As Gilbert and Gubar have shown in their book, some female writers such as the Brontës attempted to reduce patriarchal opposition to their works by adopting male pseudonyms or view points, while covertly propounding their own ideas. This double consciousness was internalized in order to come to terms with and reduce the anxiety of authorship (73). Ada does not develop this double consciousness, since instead of planning coups against patriarchy, she wages war against it, but Del develops it early on in her interactions with men. Charlotte Brontë is a role model for Del, and she herself declares so when reading about the writer's life (Lives 154). With the exception of the failed Baptism, she does not oppose patriarchy and its tenets in an outrageous way. She excels in the internalization of this double consciousness, something her mother has never been able to adopt since she equates it with duplicity and prudish provinciality.

Del clearly differentiates between intellectual and physical submission to men, and this knowledge enables her to enjoy the pleasures of the flesh they have to offer. In her encounter with Mr. Chamberlain, she retains her integrity very well. She does enjoy his sensual and secretive assaults, but when alone with him at the fields, she turns the tables on him. Playing the role of the girl who has been only recently awakened to sexuality and is still baffled by it, she turns into a voyeur, and watches Mr. Chamberlain as he masturbates and falls to sexual abandonment. She is not in the least excited or amazed at the spectacle he has put on display, instead describes the whole incident in such clinical terms (Lives 135-136) that it becomes apparent that the whole event has been an experiment on her part. A similar pattern is shown in her relations with Garnet French. She succumbs to his advances as long as they bring her gratification and relieve her of sexual tension, but when he wants to abuse the leash he has on her, she reacts by tearing it to shreds. She wonders how he could have possibly assumed that he or anyone else could have any sort of real power over her (187). She refuses to become a victim, instead opting to show her nimbleness in every move. However, Garnet is aware of Del's lack of real submission, and that is 
why he tries to force her into a baptism (Lives 187). This is probably owing to the fact that suppressors are aware that as a result of their subordination, the suppressed may harbor rebellious thoughts and only submit in appearance (Madwoman 73-4).

Adopting and developing a double consciousness has its own harmful effects, sometimes it can make the woman writer feel caged and repressed, and at other times, it can damage the work, making it look flawed (Madwoman 74). Del is not exempt from feeling this way. She has to keep her feelings to herself, and refrain from showing them, which mostly leaves her feeling repressed and unable to defend herself. When her sexual experiment with Jerry goes awry (Lives 162), Del is furious, but when faced with the patriarchal demand to be comradely, she has no choice other than to comply. Similarly, she only internally answers Jerry's sexist notions about women. Also, Del's epilogue to the short story collection, in which she details her version of Marion Sherriff, certainly looks flawed. While in the first section of this chapter, this story was discussed because of its successful fusion of the angel/monster dichotomy, here it will be discussed because of its disturbing elements. Although this story intends to depict a woman who takes control over her life, if read against the grain, shows itself to be quite fatalistic. Caroline, the sensual martyr, is a woman with serious mental issues who rushes to her doom and voluntarily courts death. Thus, the story acts as a chilling foreboding to the horror and psychological confusion awaiting the woman who tries to submit to and fight patriarchy at the same time. According to this story, one thing is certain in this woman's life, and that is her eventual demise.

\section{Infection in the Sentence: The Diseased Mother}

The literary foremothers, along with support, impart to their daughters the burden of their fight against patriarchy, thus making them afraid and ailing. This infection in the sentence "breeds" and reaches the daughter as she browses the pages written by the mother. As a result, the daughter would find it hard not to resent the mother for the metaphorical "sterility" she imposes on her creative faculties. In the case of Del, this "sterility" is quite literal. Feeding her daughter on the "black milk" of her rage against a system that limits her, Ada has been trying to prepare Del to nurse the same vendetta. But she is not the only one who issues warnings: throughout her journey, Del is haunted by women who echo her mother's words, most notably Naomi's mother (Lives 98-9). Also, society is not particularly appreciative of a woman's sex drive, and Naomi says as much when she declares rape victims to be guilty, since "a boy can't help himself" whereas girls should necessarily curb their sexual urges (110).

Throughout the work, Ada shows her resentment towards sex, considering it to be a degradation. For instance, she does not believe Fern and Mr. Chamberlain engage in sexual activities because of being superior to the town's "dirtymindedness", and calls the Gay-la Dance Hall "Sodom and Gomorrah", the appellation given the place by the Presbyterian Church (Lives 119, 147-8). She refuses to share the common belief that Marion Sherriff killed herself because of being pregnant, believing this to be a blow to her reputation (191). Also, Ada does

Logos et Littera: Journal of Interdisciplinary Approaches to Text 
not approve of Naomi because she fears the potential "contamination" of Del by her "sexual preoccupation" (119).

Murphy points out how in Munro's works, sex is compelling to young girls because of its mixture of danger and mystery (47). This certainly holds true in Del's case, since to her, sexual acts are dangerous yet extremely alluring, and in thinking about them, she alternately feels disgust and fascination (Lives 46, 39, 41, 120). She sees normality as "the skin of everyday appearances stretched over such shamelessness, such consuming explosions of lust"; thus, she is disappointed with the normal appearance of the town prostitutes and the pamphlets in Fern's bedroom $(124,133-4)$, and considers her own sexuality as treacherous (Lives 132). When daydreaming about Mr. Chamberlain (124-5), it is important to note that these thoughts do not go further than the moment of nakedness because of Del's guilt and her ignorance about how initiation is supposed to take place. Her thinking of sex as an animalistic act has resulted in her incapacity to imagine its initiation, that "stage of transition, bridge between what was possible, known and normal behaviour, and the magical, bestial act" (123-4). Therefore, one might attribute her interest in being brutalized $(124,130-1)$ to the way it would relieve her of the guilt associated with initiating her own debasement. Later on in the short story cycleand with the introduction of Garnet French-Del is able to overcome these unhealthy sexual thoughts, and fully appreciate carnal knowledge.

\section{Parable of the Cave: The Origin of All}

In her introduction to The Last Man, with its talk of the Cumeaen Sibyl, Mary Shelley relates how she came into contact with the words of wisdom written by her foremother, which she used in her literary efforts. The womb is an ultimately mystical and powerful place, where disparate elements fuse in order to give birth to a new life. Gilbert and Gubar point to a similarity between wombs and caves, declaring that "the womb-shaped cave is also the place of female power, the umbilicus mundi, one of the great antechambers of the mysteries of transformation. As herself a kind of cave, every woman might seem to have the cave's metaphorical power of annihilation" (95). The cave is the place where wandering men meet their demise, but to the cave-dweller herself, it does not pose any threats. Thus, women and their wombs have been feared, since they embody what is dangerous to men (95). In order to preserve itself, patriarchy alienated women from their caves, so that they would not have access to their destructive powers. Since men have traditionally been the guardians of the pen, they conceived of a strong similarity between their pens and the marker of their gender. Taking this into consideration, it becomes easier to understand how a woman who dared take up the pen was seen as a freak, since she was venturing to use the phallic symbol which was extremely unsuitable for her hands. She was mocked, and her literary endeavors were likened to abnormal children. Thus, women's banishment from a realm of literature was really an extension of the censure imposed on her use of feminine faculties, and as a result, by freeing one's body from restrictions, one would be able to free her mind from limits as well.

For Del, the pleasures of the flesh and the word are inextricably woven together. This is due to the fact that she sees an exploration of sexuality as a way of 
freeing the self and becoming a better writer. Just as Mary Shelley had to ponder over the coded Sibyl's leaves, Del needs to detect animal drives hidden under the façade kept up by society. Throughout the stories, there are numerous instances in which Del seems haunted by sexually-charged words and what they entail (Lives $119,126,134,147,161,140,98,123-4)$. Despite the clear link between sexuality and writing, and also contrary to the fact that her sexual experimentations liberates her as a writer, Del is dumbfounded when it comes to releasing her body through words. Confronted with Clive's command to dance him "loose", she pores over the meaning it could possibly have, and is unable to forge a link between her body and her mind (Lives 149). In a similar situation, she tries to leave her body to Jerry Storey so that he may facilitate her awakening. Lying naked on his bed, this prelude to "making love" sounds more like a grotesque parody of the first sex depicted in romances. Jerry clinically examines her, talking dialect, and urging her to play along with his game (161). This encounter is also sterile as well, since similar to the incident with Clive, it ends with Del walking home alone, ungratified. Del's sexuality is accompanied by a certain muteness, in other words, a mist clouds her mental faculties, and she becomes a woman of flesh. In her relationship with Garnet, instead of verbal communication, there is a silent exchange of sexual favors (180). At the climax of the relationship, the moment of the proposed baptism, Del finds her voice again, and walks away from him as the chiseled writer.

Walking back to Jubilee, her surroundings take on a new meaning quite different from before. In her epilogue, Del gives the reader a sense of what these new impressions entail for her career as a writer. She is interested not in Caroline, but Marion and what had actually happened to her (Lives 196-7). She can now understand how human lives are "dull, simple, amazing and unfathomable-deep caves paved with kitchen linoleum" (198), and wishes to explore their hidden depths. Her creation of the Gothic tale of Caroline was necessary in her development as a writer, since it helped her come to terms with the limits patriarchy imposed on her as a woman. But now, as she is siting with Bobby Sherriff, Marion's brother, she tells the reader how in time, she will hanker after details. She will desire nothing more than to record things, like her Uncle Craig used to do, but this obsession would be "voracious and misguided", since no one could possibly transcribe all the nuances of reality: her hunger for reserving "every last thing, every layer of speech and thought, stroke of light on bark or walls, every smell, pothole, pain, delusion, held still and held together-radiant, everlasting" will never be satiated (198-9). Del's lists would be more glorious than those of her Uncle's, since she would try to include in them all the particles that make up life, weaving the abstract and the concrete in order to create a grand tapestry. As she herself tells the readers in the voice of an omniscient narrator, she will come to yearn for this provincial town (198); Jubilee, with its conservative, old-fashioned inhabitants, shares the germ of life with the rest of the world.

Unfortunately, not all women can use the cave to their advantage, and what could have been an empowering force becomes an impediment. The woman who was subjected to the brutal rejection of her sexuality, became unable to write with a pen, a situation alien to a male writer who is so empowered in his sexuality that he sees his pen as a penis. This frustration and failure to fully achieve one's potentials 
can be detected in some of the character of Lives, most notably Addie. Addie is not successful in her language-based escape from her conservative society, but she still believes in language's redeeming power. As Cinda Gault asserts, "Addie Jordan's need to do something remarkable with language provides the impetus for her daughter to vindicate her mother's perhaps naïve faith in language by becoming a writer" (453). Therefore, Del follows her mother's path, correcting it as she deems fit, and thus brings it to its target destination. According to Janet Beer, Del's journey ends triumphantly, since at the end of the series, she rejects Garnet as a way of rejecting a fate similar to her mother and Aunt Moira, who are diseased an ailing in their marriages. Del's decision to opt for writerly exile rather than love is quite grand, considering how the stories of men recounted in the volume end "in stasis, with a funeral, with failures of imagination, refusals to change and even regression" (145-6). Just as Mary Shelley came to an understanding of her ancestor's leaves on her own, Del is essentially alone in her journey, although others may have seemed to accompany her. Howells asserts as much when she claims that "Del's love affair has confirmed her sense of isolated selfhood, while giving her some insight into the delicious rhythms of her own body and of the painful contradictions between fantasy and reality" ("Secrets and Discoveries" 46). The relationship with Garnet completes Del's Küntslerroman, bringing her a better understanding of life and making her a free woman, both of which are important in her career as a writer.

\section{Conclusion}

In the course of this research, Alice Munro's short story collection entitled Lives of Girls and Women was read in terms of some notions developed by Gilbert and Gubar, so as to arrive at a better understanding of the journey its heroine undertakes in order to shape her character as a writer and a woman.

Considering the short story cycle for its portrayals of the angel/monster dichotomy, it can be seen that Del refuses to be limited by either of these sides, instead, juxtaposes the ordinary and the domestic with the wildly sexual so as to do away with them. Other than that, she transcends the dichotomy by the way she portrays two women in her stories, namely, her mother and Marion Sherriff.

Ada does not show signs of being possessed by the anxiety of authorship, since she fully believes in the righteousness of her path. On the other hand, Del is seen as suffering the pangs of this anxiety, as she can witness the resentment her mother's writerly tendencies incite in people.

Checking Ada and Del for their possession of female double consciousness, one can see that since Ada does not suffer from the anxiety of authorship, she has not developed the double consciousness either. On the other hand, Del has resorted to this double consciousness as a way of alleviating her anxiety.

Del is shown to have contracted the infection in the sentence from her mother, since she has plied Del with stories of how devious sexuality is and how it can endanger a woman's autonomy. As a result of this, Del is quite unable to conceive of a healthy sexual relationship; instead, she views the act as an evil and violent deed.

Logos et Littera: Journal of Interdisciplinary Approaches to Text 
Just like Mary Shelley in the parable of the cave, Del embarks on a journey to understand the coded messages of her predecessor and come to a better understanding of them. Since writing and sexuality are closely linked with each other, Del's exploration of her female space brings about a liberation of her literary energies as well. In her explorations, she experiments with different companions before settling on Garnet as the suitable one.

\section{References}

Beer, Janet. "Short Fiction with Attitude: The Lives of Boys and Men in the Lives of Girls and Women." Bloom's Modern Critical Views: Alice Munro. Ed. Harold Bloom. Infobase Publishing, 2009. 143-151.

Beran, Carol L. "Images of Women's Power in Contemporary Canadian Fiction by Women." Studies in Canadian Literature/Études en littérature canadienne 15. 2 (1990): N. pag.

Chang, Jungyoon. “Girls and Gender in Alice Munro's Short Stories.” Asian Women 32.2 (Summer 2016): 27-47.

Dahlie, Hallvard. "Alice Munro." Canadian Writers and Their Works. Ed. Robert Lecker, Jack David, and Ellen Quigley. Vol. 7. 1985. 215-256.

Douglas, Ann. The Feminization of American Culture. Knopf, 1977.

Gault, Cinda. "The Two Addies: Maternity and Language in William Faulkner's As I Lay Dying and Alice Munro's Lives of Girls and Women." The American Review of Canadian Studies 36.3 (Fall 2006): 440-57.

Gilbert, Sandra M., Susan Gubar. The Madwoman in the Attic: The Woman Writer and the Nineteenth-Century Literary Imagination. Yale Nota Bene, 2000.

Glover, Douglas. "The style of Alice Munro." The Cambridge Companion to Alice Munro. Ed. David Staines. Cambridge University Press, 2016. 86-110.

Hay, Elizabeth. "The Mother as Material." The Cambridge Companion to Alice Munro. Ed. David Staines. Cambridge University Press, 2016. 267-283.

Howells, Coral A. "Alice Munro: Lives of Girls and Women, The Beggar Maid." Private and Fictional Words: Canadian Women Novelists of the 1970s and 1980s. Routledge, 1987. 71-88.

---, "Secrets and Discoveries: Lives of Girls and Women." Alice Munro. Manchester University Press, 1998. 31-50.

Löschnigg, Maria. “'Oranges and Apples': Alice Munro's Undogmatic Feminism.” The Cambridge Companion to Alice Munro. Ed. David Staines. Cambridge University Press, 2016. 111-142.

Munro, Alice. "A Conversation with Alice Munro." Interview by John Metcalf. Journal of Canadian Fiction 1.4 (1972): N. pag.

---, Lives of Girls and Women: A Novel. Penguin Group, 2009.

Murphy, Georgean. "The Art of Alice Munro: Memory, Identity, and the Aesthetics of Connection." Bloom's Modern Critical Views: Alice Munro. Ed. Harold Bloom. Infobase Publishing, 2009. 41-56.

Ortner, Sherry B. "Is Female to Male as Nature is to Culture?" Woman, Culture, and Society. Ed. Michelle Zimbalist Rosaldo and Louise Lamphére. Stanford University Press, 1974. N. pag. 
Ross, Catherine Sheldrick. "Alice Munro." In Dictionary of Literary Biography, edited by W. H. New. Vol.53. Gale Research Inc., 1986.

Staines, David. "From Wingham to Clinton: Alice Munro in Her Canadian Context." The Cambridge Companion to Alice Munro. Ed. Staines. Cambridge University Press, 2016. 23-54.

Thacker, Robert. "Introduction: Alice Munro's 'Approach and Recognition.'” Alice Munro: 1973-2013. University of Calgary Press, 2016. 1-19.

Wilmot, John. "Timon, A Satyr." Poems by John Wilmot the Earl of Rochester. Ed. Vivien de Sola Pinto. Routledge and Kegan Paul, 1953. N. pag. 